\title{
Androgen receptor knockout and knock-in mouse models
}

\author{
S Kerkhofs, S Denayer, A Haelens and F Claessens \\ Molecular Endocrinology Laboratory, Department of Molecular Cell Biology, University of Leuven, Campus Gasthuisberg O\&N1, PO Box 901 , Herestraat 49, BE-3000 Leuven, Belgium
}

(Correspondence should be addressed to F Claessens; Email: frank.claessens @med.kuleuven.be)

\begin{abstract}
Androgens play an important role in male reproductive development and function. These steroid hormones mediate their actions by binding to the androgen receptor (AR). Diseases such as androgen insensitivity syndrome, prostate cancer, Kennedy's disease, and infertility can be caused by mutations in the AR. To get a better insight into the molecular working mechanisms of the AR, several knockout and knock-in mouse models have been developed. These models are reviewed here and are compared with human diseases.
\end{abstract}

Journal of Molecular Endocrinology (2009) 42, 11-17

\section{Introduction}

Androgens are steroid hormones, which play an important role in the development and maintenance of male characteristics. The two most important androgens are testosterone and $5 \alpha$-dihydrotestosterone (DHT). Each of them plays a distinct role during male sexual development. Testosterone is crucial for the development and differentiation of Wolffian duct derived structures such as the epididymis, seminal vesicles, and vas deferens, whereas $5 \alpha$-DHT triggers the development and differentiation of male urogenital structures (male external genitalia, urethra, and prostate; Wilson et al. 1993, Nef \& Parada 2000).

To mediate their actions, testosterone, and DHT bind to the intracellular androgen receptor (AR), a ligandinducible transcription factor belonging to the nuclear receptor superfamily. The gene encoding the AR is located at position q11-12 on the X-chromosome and comprises eight exons. It encodes a protein of 919 amino acids with a molecular mass of $\sim 110 \mathrm{kDa}$ (Lubahn et al. 1988). The AR possesses an overall structure similar to that of the other nuclear receptors. It consists of four functional domains: an amino-terminal transactivation domain (NTD, encoded by exon 1) containing stretches of glutamine, proline, and glycine, a highly conserved central DNA-binding domain (DBD, encoded by exons 2 and 3 ), a hinge region (encoded by the $5^{\prime}$ part of exon 4 ) and a carboxy-terminal ligand-binding domain (encoded by the $3^{\prime}$ part of exon 4 and exons 5-8; Tsai \& O'Malley 1994, Lee \& Chang 2003). Liganded AR binds as a homodimer to specific DNA motifs called androgen response elements (AREs) that are situated in or near target genes (Wang et al. 2007). These AREs can be divided in two classes: the classical AREs also recognized by the other steroid receptors and the selective AREs, which display selectivity for the AR (Claessens et al. 2001, Shaffer et al. 2004).

Due to the location of the AR gene on the $\mathrm{X}$-chromosome and its role in male fertility, mutant AR genes affect males, whereas females carry and transmit the gene to the next generation. Malfunctioning ARs can be associated with different diseases such as prostate cancer, androgen insensitivity syndrome (AIS), Kennedy's disease, and infertility. Initial studies on androgen action involved castration and transplantation experiments combined with hormone injection (Jost 1953). More recently, molecular biological analyses lead to a more detailed view on the AR mechanism of action and on the specifics of the physiological role of androgens. However, to further the in vivo studies, the development of AR knockout and knock-in mouse models are crucial. Here, we review the different models and compare them with human diseases.

\section{Comparison of complete AIS with the AR knockout mouse model}

AIS is a rare $\mathrm{X}$-linked recessive disorder with a prevalence of 1:20 400 male births (Poletti et al. 2005). In most cases, cAIS is caused by a mutation of the AR gene (Quigley et al. 1995). To date, about 400 different mutations (single base mutations, nucleotide insertions or deletions, intronic mutations, and partial or complete gene deletions) have

DOI: 10.1677/JME-08-0122 Online version via http://www.endocrinology-journals.org 
been identified in cAIS (http://androgendb.mcgill.ca/ AR23C.pdf). These mutations lead to androgen insensitivity via different mechanisms: incomplete synthesis of the AR protein, inability of androgen binding by the AR or abnormalities in binding of the androgen-AR complex to AREs (Quigley et al. 1995, Gottlieb et al. 1999, 2004, Poletti et al. 2005).

The differential effect of the AR mutations results in a wide clinical spectrum of phenotypes ranging from a fully female external phenotype (complete AIS, previously known as testicular feminization (Tfm) syndrome) to an undervirilized male phenotype (partial AIS) of $46 \mathrm{XY}$ individuals (Quigley et al. 1995). Individuals with cAIS are genetically male but exhibit a female phenotype. They have female external genitalia, small or normal clitoris and a blind ending vagina. The internal female genitals (uterus and Fallopian tubes) are absent because the secretions of the AMH during fetal life by the Sertoli cells are normal. The Wolffian duct derivatives and the prostate are absent. The undescended testes are located in the abdomen, the inguinal canal or in sacs of bilateral hernias. Development of gynecomastia is the same as in $\mathrm{XX}$ females and in the majority of cases axillary and pubic hair is absent (Quigley et al. 1995, Brinkmann 2001, Poletti et al. 2005). LH and plasma testosterone concentrations are elevated at puberty and in adults (Larsen et al. 2003).

The first animal model of androgen insensitivity was described in 1970 by Lyon and Hawkes. They reported an X-linked gene for Tfm in the mouse (Lyon \& Hawkes 1970). The Tfm/Y mice carry a single nucleotide deletion in exon 1 of the AR gene, which introduces a premature termination of AR translation (Gaspar et al. 1991). Tfm/Y mice are infertile and their testes are smaller compared with WT mice. The testes are located in the inguinal region, comparable with some patients with cAIS (Couse $\&$ Korach 1998). These and other studies revealed that testicular descent is a biphasic process in which the second phase, the so-called inguinoscrotal migration, is androgen dependent (Hutson et al. 1994).

Besides this Tfm model, there are several transgenic mice models with a ubiquitous knockout of the AR (ARKO). The generation of these ARKO mouse models involves two transgenic mouse strains: a Cre transgenic mouse that expresses the recombinase ubiquitously and a mouse strain in which part of the AR gene is flanked by loxP sites (Table 1; Sauer 1998). Two ARKO mouse models were developed in which exon 2 was flanked by loxP sites (Yeh et al. 2002, De Gendt et al. 2004). These floxed AR mice were crossed with mice carrying Cre recombinase under the control of $\beta$-actin (Yeh et al. 2002) or under the control of the PGK promoter (De Gendt et al. 2004). Two other groups floxed the first exon of the AR that codes the complete AR-NTD. Matsumoto et al. crossed these mice with mice expressing Cre under the control of a CMV promoter (Matsumoto et al. 2003). The other group placed the loxP sites in opposite directions
Table 1 Summary of the five ARKO mouse models

\begin{tabular}{|c|c|c|c|}
\hline & $\begin{array}{l}\text { Floxed } \\
\text { exon }\end{array}$ & $\begin{array}{l}\text { Promotor of } \\
\text { Cre recombin- } \\
\text { ase }\end{array}$ & $\begin{array}{l}\text { T levels } \\
\text { versus } \\
\text { WT }\end{array}$ \\
\hline $\begin{array}{l}\text { ARKO 1, Yeh et al. } \\
(2002)\end{array}$ & Exon 2 & $\beta$-Actin & $\downarrow$ \\
\hline $\begin{array}{l}\text { ARKO 2, De Gendt } \\
\text { et al. (2004) }\end{array}$ & Exon 2 & PGK & $=$ \\
\hline $\begin{array}{l}\text { ARKO 3, Matsumoto } \\
\text { et al. (2003) }\end{array}$ & Exon 1 & CMV & $\downarrow$ \\
\hline $\begin{array}{l}\text { ARKO 4, Holdcraft \& } \\
\text { Braun (2004a) }\end{array}$ & Exon 1 & Sycp1 and ella & l \\
\hline $\begin{array}{l}\text { ARKO 5, Notini } \\
\text { et al. (2005) }\end{array}$ & Exon 3 & CMV & $\downarrow$ \\
\hline
\end{tabular}

around exon 1. These mice were mated with Sycp1-Cre and eIIa-Cre mice and this resulted in mice with an inverted exon 1 (Holdcraft \& Braun 2004a). In the model, developed by Notini et al. (2005), exon 3 (encoding the second zinc finger of the DBD) of the AR gene is floxed. Subsequently, the floxed AR mice were bred with CMV-Cre mice to generate ARKO mice in which only the third exon of the AR has been deleted. A comparable mutation is found in a pair of siblings with cAIS (Quigley et al. 1992).

The phenotype of the different ARKO males is comparable with the phenotype of the male Tfm mouse. They all have a female-like external appearance, testes are reduced in size and located intra-abdominally, Wolffian duct derived structures are absent, there is no vaginal opening, Fallopian tubes or uterus and LH levels are increased. Only one of the five developed ARKO mice models showed late onset of obesity (Matsumoto et al. 2003).

In contrast to what is observed in cAIS patients, there are always spermatogonia and early spermatocytes present in testes of Tfm mice and these mice have low levels of circulating testosterone (Lyon \& Hawkes 1970, Couse \& Korach 1998). The serum testosterone concentrations in ARKO males are equal or even decreased compared with WT males (Table 1). In $\mathrm{Tfm} / \mathrm{Y}$ mice, gonadotropins ( $\mathrm{LH}$ and $\mathrm{FSH}$ ) are increased, while testosterone levels are significantly lower than in WT mice (Naik et al. 1984). The germ cells of the $\mathrm{Tfm} / \mathrm{Y}$ mice almost never proceed beyond the spermatocyte stage. It is not clear whether this spermatogenic phenotype is caused by a defective gene action in the germ cells or by an unspecific effect of cryptorchidism (Lyon \& Hawkes 1970).

\section{Cell-specific roles of AR in the testis}

Spermatogenesis is dependent on gonadotropins and testosterone. FSH is needed for the stimulation of Sertoli 
cell proliferation and the initiation of spermatogenesis and together with high levels of intratesticular testosterone (produced via LH action on Leydig cells), FSH is important for the maintenance of the spermatogenic process in humans as well as in mice (Dohle et al. 2003). However, in mice androgens alone (low intratesticular androgen levels) can initiate spermatogenesis in the complete absence of FSH (Singh et al. 1995). This has been confirmed in the FSH receptor and FSH $\beta$-subunit knockout mice, which display normal fertility, albeit with smaller testis and reduced germ cell numbers (Kumar et al. 1997, Huhtaniemi \& Aittomaki 1998, Abel et al. 2000, Wreford et al. 2001). Mutations in the AR gene in humans can also lead to defective spermatogenesis (Yong et al. 2003, Zuccarello et al. 2008). Spermatogenesis in the ARKO mice is arrested at the pachytene spermatocyte stage, but it is unclear whether this is a direct effect of the knockout or of the abdominal location of the ARKO testes (Johnston et al. 2001, Holdcraft \& Braun 2004b). In the testis, we can distinguish somatic cells like Sertoli cells, Leydig cells and peritubular myoid cells, which are all AR positive (Bremner et al. 1994, Vornberger et al. 1994, Zhou et al. 2002). Whether germ cells express the AR is still controversial but mice with a germ cell selective knockout of the AR have normal spermatogenesis (Tsai et al. 2006). Using the spermatogonial stem cell transplantation technique, Johnston et al. (2001) concluded that testicular germ cells from the Tfm mice can complete spermatogenesis when they are transplanted in the seminiferous tubules of azoospermic mice expressing functional ARs. Comparison of Tfm mice with wild-type mice, however, showed that gonocytes, the precursors of the germ cells, are AR positive, and their numbers seem to be controlled by androgens (Merlet et al. 2007).

Sertoli cells are generally believed to be the primary mediators of the androgen regulation of spermatogenesis because they provide physical and nutritional support to the developing germ cells (Griswold 1998). To examine this hypothesis, three mouse models in which the AR is knocked out selectively in Sertoli cells have been reported (Chang et al. 2004, De Gendt et al. 2004, Holdcraft \& Braun 2004a). In the first study, mice with a floxed exon 2 of the AR were crossed with mice expressing the Cre recombinase driven by the $\mathrm{AMH}$ promoter (AMH-Cre), which is selectively expressed in Sertoli cells (De Gendt et al. 2004). In comparison with ARKO males, Sertoli cell selective AR knockout (SCARKO) males show a normal external male appearance and have normal internal male genital tracts. The SCARKO males have fully descended testes but the size of the testis is markedly reduced. Despite the normal Sertoli cell nuclear volume per SCARKO testis, spermatogenesis appears to be blocked in meiosis since spermatocytes, round spermatids, and elongated spermatids are reduced to $64,3,0 \%$ respectively (De Gendt et al. 2004, Tan et al. 2005). Because SCARKO testes contain normal number of Sertoli cells we can conclude that the effect of androgens on the number of Sertoli cells is mediated by a mechanism that does not involve functional AR in Sertoli cells themselves (Tan et al. 2005). More detailed analysis of the SCARKO testes revealed the role of the AR in the maintenance of the cell-cell contacts between the Sertoli cells and the developing germ cells (Denolet et al. 2006). A second mouse model with a Sertoli cell specific ablation of the $\mathrm{AR}\left(\mathrm{S}-\mathrm{AR}^{-/ \mathrm{y}}\right)$ was obtained with the same strategy as in De Gendt et al. (Chang et al. 2004, Tsai et al. 2006). The $\mathrm{S}_{-} \mathrm{AR}^{-/ \mathrm{y}}$ phenotype is comparable with the SCARKO phenotype but spermatogenesis is arrested in the premeiotic diplotene spermatocyte stage in $\mathrm{S}_{-} \mathrm{AR}^{-/ \mathrm{y}}$ and $\mathrm{S}-\mathrm{AR}^{-/ \mathrm{y}}$ mice have decreased testosterone and increased LH serum levels. By contrast, the concentration of these hormones in SCARKO males is comparable with WT males. In another model, the first exon of the AR is flanked with inverted loxP sites and a neomycin resistance cassette is introduced in intron 1 (Holdcraft \& Braun 2004a). This cassette seems to create a hypomorphic allele of the AR gene (Meyers et al. 1998). These hypomorphic animals $\left(\mathrm{Ar}^{\mathrm{flox}(\mathrm{ex} 1+\mathrm{neo}) / \mathrm{Y}}\right)$ were mated with a different $\mathrm{AMH}$ expressing mouse strain than used by the other two groups to generate a partial Sertoli cell specific ARKO ( $\mathrm{Ar}^{\text {flox }(\mathrm{ex} 1+\text { neo }) / Y}$; AMH-Cre $)$. Spermatogenesis in $\mathrm{Ar}^{\text {flox }(\operatorname{ex} 1+\text { neo }) / Y}$; AMH-Cre males is not blocked as in SCARKO and S-AR ${ }^{-/ y}$ but a defect occurs during the transition of round to elongated spermatids. Possibly, this discrepancy is caused by the

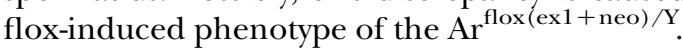

A recent mouse model lacking FSHR and AR on Sertoli cells (FSHRKO-SCARKO) was developed to determine the compounded effects of these hormones on Sertoli cell function and spermatogenesis. Meiosis in these animals is initiated, but the completion of meiosis is absolutely dependent on the expression of the AR (Abel et al. 2008).

The AR is also expressed abundantly in the mature Leydig cells. Knocking out the AR selectively in Leydig cells by Amhr2 driven Cre strategy $\left(\mathrm{L}^{-\mathrm{AR}^{-/ \mathrm{y}}}\right.$ ) results in mice with decreased size of testis and epididymis, reduced serum levels of testosterone and increased serum levels of LH and FSH. This indicates the feedback of testosterone synthesis and AR expression in the Leydig cells and FSH and LH expression in the pituitary. It is important to note that the AR knockout in Leydig cells in this model was not complete. $\mathrm{LAR}^{-/ \mathrm{y}}$ mice are infertile and spermatogenesis is arrested predominantly at the round spermatid stage (Tsai et al. 2006, Xu et al. 2007). A selective ablation of the AR in Sertoli cells also has consequences for the development of normal Leydig cell numbers. Compared with controls, SCARKO mice have a normal or increased Leydig cell size, while in ARKO mice the size of the Leydig cells is reduced (De Gendt et al. 2005). 
Peritubular myoid cells are the AR positive cells surrounding the seminiferous tubules in the testis. These cells may play an indirect role in spermatogenesis through the control and maintenance of the Sertoli cell function as well as in the transport of spermatozoa through the tubular lumen by contractions of the seminiferous tubules (Maekawa et al. 1996, Romano et al. 2005). Indeed, peritubular myoid cell selective AR knockout mouse have a decreased testis size and oligozoospermia, but the fertility is normal (Zhang et al. 2006).

From the results of the AR knockout models we can conclude that the AR has specific roles in different cell types of the testis. Activity of the AR plays an important role during at least three steps of spermatogenesis: first, the AR is necessary for progression through meiosis I, secondly, the transition from round to elongated spermatids requires AR activity, and finally AR is important during the terminal stages of spermiogenesis (Fig. 1; Holdcraft \& Braun 2004b, Xu et al. 2007).

\section{AR and knock-in mouse models}

The in vitro molecular study of the AR has provided many new insights into its action mechanism in normal and pathological conditions that urgently need verifications in in vivo settings (Claessens et al. 2008). For this, several 'knock-in' strategies have been developed. This technique was used to develop a mouse model for Kennedy's disease. Kennedy's disease or spinal and bulbar muscular atrophy (SBMA) is caused by an abnormal expansion of a CAG triplet repeat in the first exon of the AR gene, corresponding to a polyglutamine stretch in the NTD. This disease is characterized by proximal muscle weakness, fasciculations, and atrophy. Some patients display additional clinical features like androgen insensitivity, severe oligozoospermia or azoospermia, testicular atrophy, feminized skin changes, and gynecomastia (Arbizu et al. 1983, Casella et al. 2001). Different mouse models are developed in which exon 1 of mouse AR was swapped with human exon 1 and during this process 12, 21, 48 or 113 CAG repeats were inserted (Albertelli et al. 2006, Yu et al. 2006b). The first three mouse models show comparable growth, behavior, reproductive tract morphology, and fertility as WT littermates. However, AR113Q mice develop hormone-dependent neuromuscular pathology. Mutant males, aged between 3-5 months, develop muscle pathology and only at 24 months the spinal cord pathology can be detected. Eighty percent of the males die at $2-4$ months of age. This early death is dependent upon circulating testosterone and is probably caused by acute urinary tract obstruction. This obstruction is caused by altered muscle membrane excitability in the lower urinary tract of AR113Q males (Yu et al. 2006a). The weight of the testes of AR113Q males is reduced to

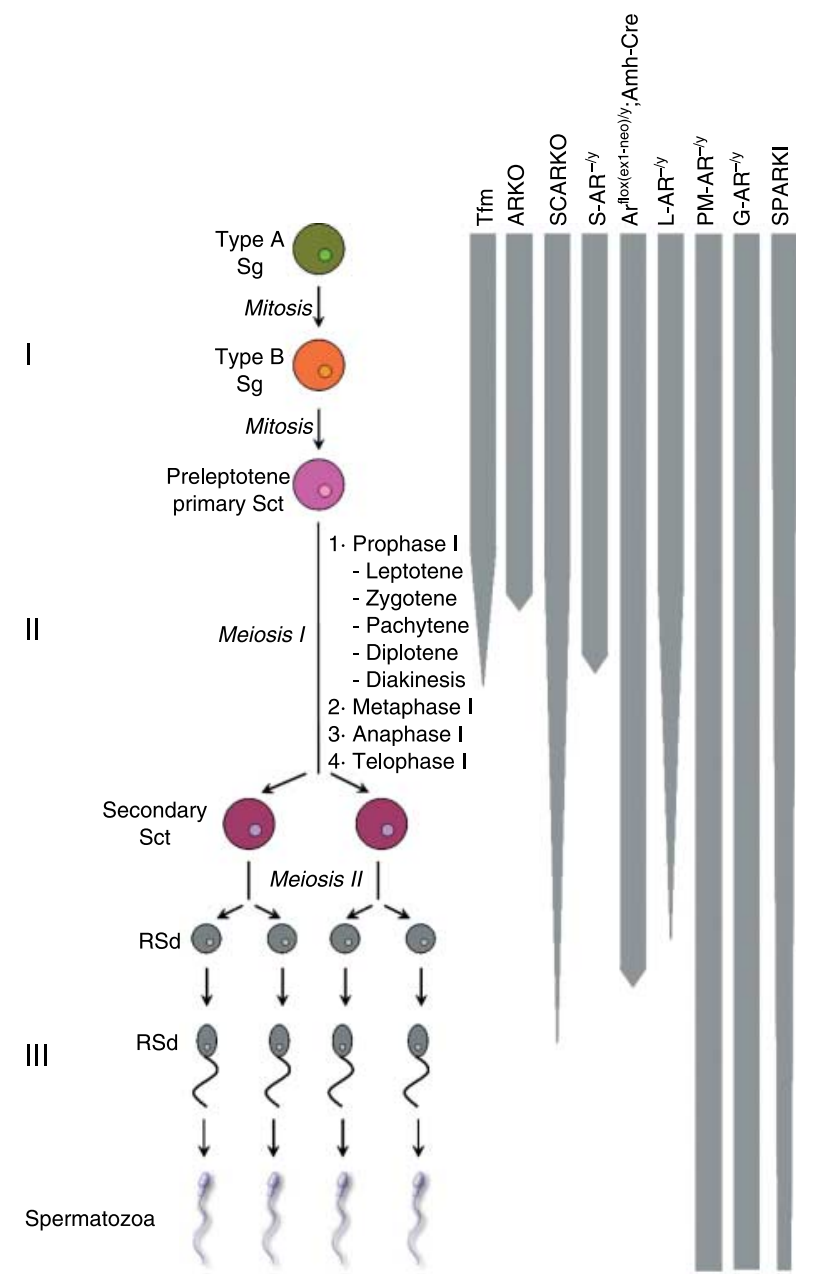

Figure 1 Schematic of spermatogenesis and the different knockout and knock-in mouse models. Spermatogenesis can be divided into three phases: (I) proliferative phase, (II) meiotic phase, and (III) spermiogenesis (Sg, spermatogonia; Sct, spermatocytes; $\mathrm{RSd}$, round spermatids; ESd, elongated spermatids).

$50 \%$ of WT testes and they have decreased fertility. Serum testosterone levels are comparable with WT, serum LH levels are elevated and serum FSH levels are decreased. These observations show that AR113Q males display signs of partial androgen insensitivity that commonly occur in Kennedy's disease patients. The testicular pathology in the AR113Q male mice progresses with increasing age and is characterized by abnormal germ cell maturation (large multinucleated cells, decrease of epididymal sperm and increase of TUNEL-positive cells) and abnormalities of the Sertoli cell cytoskeleton. The solubility of the mutant AR in protein lysates is decreased and the mutant AR protein forms complexes in testes but these complexes could not be detected by conventional morphological methods. Yu et al. (2006b) concluded that the testicular phenotype is mediated by toxic effects of the mutant $\mathrm{AR}$ protein rather than a partial loss of $\mathrm{AR}$ 
function, however; hypothalamic dysfunction or changed levels of estrogens or inhibin can also contribute to the testicular pathology.

AR knock-in mouse models are not only developed to get a better insight into diseases like SBMA but also to study the normal working mechanism of the AR. The androgen-AR complex can bind as a dimer to classical AREs (recognized by the other steroid receptors) or selective AREs (not recognized by the glucocorticoid receptor, GCR). To investigate, the in vivo relevance of these selective AREs, a knock-in mouse model, called specificity affecting AR knock-in (SPARKI), was developed in which the second zinc finger of the DBD and the first three amino acids of the carboxy terminal extension (encoded by exon 3 of the AR gene) are swapped with that of the GCR (Schauwaers et al. 2007). In vitro analysis showed that the SPARKI-AR lost its ability to bind to selective AREs, but still can bind classical AREs. Phenotypically, SPARKI males have normal body weights and the amount of body fat, muscle, and bone is comparable with WT males indicating that selective AREs are not essential for the anabolic effects of androgens. The reproductive organs of SPARKI males are reduced in size and weight and they are subfertile. They have normal levels of total testosterone and gonadotropic hormones, which suggest that the androgen responsiveness of the pituitary feedback system is unaffected. SPARKI testes have reduced Sertoli cell numbers, which is also seen in ARKO males but not in SCARKO males suggesting that androgen effects on Sertoli cell number are mediated by a process dependent on selective AREs but outside of the Sertoli cell. Meiosis in SPARKI testes is not completely blocked but the number of round and elongated spermatids are reduced by respectively 47 and $44 \%$, an indication of an effect at the same stage as in ARKO (Fig. 1). As expected, androgen regulated genes are differentially affected by the SPARKI mutation. The expression of $R h o x 5$, aquaporin-5, and Rad9, genes that contain selective AREs, is reduced in SPARKI testes, while the expression of the Spinlw1 gene, controlled by a classical ARE, is not affected (Schauwaers et al. 2007, Moehren et al. 2008). These results indicate that the in vitro classification of AREs based on in vitro data has in vivo relevance. Similarly, other AR-specific functions, such as the N/C interactions, the co-activator recruitment to its NTD should now be verified in vivo by similar knock-in mouse models.

\section{Androgen reporter mice}

Androgen reporter mice are mice with androgenresponsive enhancers cloned upstream of reporter genes inserted in their genome. Prostate-specific models e.g. have been made using $h K 2$, PSA, and rPB regulatory elements, which allow the study of prostate specific gene expression (Seethammagari et al. 2006). However, systemic analysis of the androgen response in vivo, analogous to the estrogen reporter mice, is hampered by the fact that AR, GCR, PR, and MR all recognize very similar response elements (Ciana et al. 2003, Lemmen et al. 2004). The more selective AREs might provide a solution (Claessens et al. 2001). Such androgen reporter mice would be very useful for the in vivo study of the androgen response, the role of co-activators, possible crosstalk with other signaling pathways and even pharmacological studies.

In the mean time, an AR activity indicator (ARAI) mouse was made (Ye et al. 2005). In the ARAI mice, exons 2 and 3 encoding the AR-DBD are swapped with a GAL4 DBD cassette. This modified AR can target a reporter gene driven by GAL4 upstream activation sequences. Cross-breeding of this transgenic mouse with knockout models of the steroid receptor co-activator 1 and 2 showed that AR activity in the testis was decreased by loss of steroid receptor co-activator (SRC)-2, while ablation of SRC-1 showed surprising increase of AR activity. Experiments like these are much needed for the in vivo study of the many $\mathrm{AR}$ action mechanisms that have been proposed mainly on the basis of in vitro data.

\section{Declaration of interest}

The authors have nothing to disclose. The authors declare that there is no conflict of interest that would prejudice the impartiality of this scientific work.

\section{Funding}

This work was supported by grants from the 'Bijzonder Onderzoeksfonds' of the University of Leuven and the 'Fonds voor Weterschappelijk Onderzoek-Vlaanderen'.

\section{Acknowledgements}

We wish to thank all members of the Molecular Endocrinology Laboratory for interesting discussions and helpful suggestions. A H is a postdoctoral fellow of the 'Fonds voor Wetenschappelijk OnderzoekVlaanderen'.

\section{References}

Abel MH, Wootton AN, Wilkins V, Huhtaniemi I, Knight PG \& Charlton HM 2000 The effect of a null mutation in the folliclestimulating hormone receptor gene on mouse reproduction. Endocrinology 141 1795-1803.

Abel MH, Baker PJ, Charlton HM, Monteiro A, Verhoeven G, De Gendt K, Guillou F \& O'Shaughnessy PJ 2008 Spermatogenesis and sertoli cell activity in mice lacking sertoli cell receptors for folliclestimulating hormone and androgen. Endocrinology 149 3279-3285. 
Albertelli MA, Scheller A, Brogley M \& Robins DM 2006 Replacing the mouse androgen receptor with human alleles demonstrates glutamine tract length-dependent effects on physiology and tumorigenesis in mice. Molecular Endocrinology 20 1248-1260.

Arbizu T, Santamaria J, Gomez JM, Quilez A \& Serra JP 1983 A family with adult spinal and bulbar muscular atrophy, X-linked inheritance and associated testicular failure. Journal of the Neurological Sciences $\mathbf{5 9}$ 371-382.

Bremner WJ, Millar MR, Sharpe RM \& Saunders PT 1994 Immunohistochemical localization of androgen receptors in the rat testis: evidence for stage-dependent expression and regulation by androgens. Endocrinology 135 1227-1234.

Brinkmann AO 2001 Molecular basis of androgen insensitivity. Molecular and Cellular Endocrinology 179 105-109.

Casella R, Maduro MR, Lipshultz LI \& Lamb DJ 2001 Significance of the polyglutamine tract polymorphism in the androgen receptor. Urology 58 651-656.

Chang C, Chen YT, Yeh SD, Xu Q, Wang RS, Guillou F, Lardy H \& Yeh S 2004 Infertility with defective spermatogenesis and hypotestosteronemia in male mice lacking the androgen receptor in Sertoli cells. PNAS 101 6876-6881.

Ciana P, Raviscioni M, Mussi P, Vegeto E, Que I, Parker MG, Lowik C \& Maggi A 2003 In vivo imaging of transcriptionally active estrogen receptors. Nature Medicine 9 82-86.

Claessens F, Verrijdt G, Schoenmakers E, Haelens A, Peeters B, Verhoeven G \& Rombauts W 2001 Selective DNA binding by the androgen receptor as a mechanism for hormone-specific gene regulation. Journal of Steroid Biochemistry and Molecular Biology 76 23-30.

Claessens F, Denayer S, Van Tilborgh N, Kerkhofs S, Helsen C \& Haelens A 2008 Diverse roles of androgen receptor (AR) domains in AR-mediated signaling. Nuclear Receptor Signaling 6 e008.

Couse JF \& Korach KS 1998 Exploring the role of sex steroids through studies of receptor deficient mice. Journal of Molecular Medicine 76 497-511.

Denolet E, De Gendt K, Allemeersch J, Engelen K, Marchal K, Van Hummelen P, Tan KA, Sharpe RM, Saunders PT, Swinnen JV et al. 2006 The effect of a Sertoli cell - selective knockout of the androgen receptor on testicular gene expression in prepubertal mice. Molecular Endocrinology 20 321-334.

Dohle GR, Smit M \& Weber RF 2003 Androgens and male fertility. World Journal of Urology 21 341-345.

Gaspar ML, Meo T, Bourgarel P, Guenet JL \& Tosi M 1991 A single base deletion in the $\mathrm{Tfm}$ androgen receptor gene creates a short-lived messenger RNA that directs internal translation initiation. PNAS 88 8606-8610.

De Gendt K, Swinnen JV, Saunders PT, Schoonjans L, Dewerchin M, Devos A, Tan K, Atanassova N, Claessens F, Lecureuil C et al. 2004 A Sertoli cell - selective knockout of the androgen receptor causes spermatogenic arrest in meiosis. PNAS 101 1327-1332.

De Gendt K, Atanassova N, Tan KA, de Franca LR, Parreira GG, McKinnell C, Sharpe RM, Saunders PT, Mason JI, Hartung S et al. 2005 Development and function of the adult generation of Leydig cells in mice with Sertoli cell - selective or total ablation of the androgen receptor. Endocrinology 146 4117-4126.

Gottlieb B, Beitel LK, Lumbroso R, Pinsky L \& Trifiro M 1999 Update of the androgen receptor gene mutations database. Human Mutation 14 103-114.

Gottlieb B, Beitel LK, Wu JH \& Trifiro M 2004 The androgen receptor gene mutations database (ARDB): 2004 update. Human Mutation 23 $527-533$.

Griswold MD 1998 The central role of Sertoli cells in spermatogenesis. Seminars in Cell and Developmental Biology 9 411-416.

Holdcraft RW \& Braun RE $2004 a$ Androgen receptor function is required in Sertoli cells for the terminal differentiation of haploid spermatids. Development 131 459-467.

Holdcraft RW \& Braun RE $2004 b$ Hormonal regulation of spermatogenesis. International Journal of Andrology 27 335-342.
Huhtaniemi IT \& Aittomaki K 1998 Mutations of follicle-stimulating hormone and its receptor: effects on gonadal function. European Journal of Endocrinology 138 473-481.

Hutson JM, Baker M, Terada M, Zhou B \& Paxton G 1994 Hormonal control of testicular descent and the cause of cryptorchidism. Reproduction, Fertility, and Development 6 151-156.

Johnston DS, Russell LD, Friel PJ \& Griswold MD 2001 Murine germ cells do not require functional androgen receptors to complete spermatogenesis following spermatogonial stem cell transplantation. Endocrinology 142 2405-2408.

Jost A 1953 Problems of fetal endocrinology. The gonadal and hypophyseal hormones. Recent Progress in Hormone Research 8 379-418.

Kumar TR, Wang Y, Lu N \& Matzuk MM 1997 Follicle stimulating hormone is required for ovarian follicle maturation but not male fertility. Nature Genetics 15 201-204.

Larsen PR, Kronenberg HM, Melmed S \& Polonsky KS 2003. Williams Textbook of Endocrinology. 10 edn, Philadelphia, PA: Saunders.

Lee HJ \& Chang C 2003 Recent advances in androgen receptor action. Cellular and Molecular Life Sciences 60 1613-1622.

Lemmen JG, Arends RJ, van der Saag PT \& van der Burg B 2004 In vivo imaging of activated estrogen receptors in utero by estrogens and bisphenol A. Environmental Health Perspectives 112 1544-1549.

Lubahn DB, Joseph DR, Sar M, Tan J, Higgs HN, Larson RE, French FS \& Wilson EM 1988 The human androgen receptor: complementary deoxyribonucleic acid cloning, sequence analysis and gene expression in prostate. Molecular Endocrinology 2 1265-1275.

Lyon MF \& Hawkes SG 1970 X-linked gene for testicular feminization in the mouse. Nature 227 1217-1219.

Maekawa M, Kamimura K \& Nagano T 1996 Peritubular myoid cells in the testis: their structure and function. Archives of Histology and Cytology 59 1-13.

Matsumoto T, Takeyama K, Sato T \& Kato S 2003 Androgen receptor functions from reverse genetic models. Journal of Steroid Biochemistry and Molecular Biology 85 95-99.

Merlet J, Racine C, Moreau E, Moreno SG \& Habert R 2007 Male fetal germ cells are targets for androgens that physiologically inhibit their proliferation. PNAS 104 3615-3620.

Meyers EN, Lewandoski M \& Martin GR 1998 An Fgf8 mutant allelic series generated by Cre- and Flp-mediated recombination. Nature Genetics 18 136-141.

Moehren U, Denayer S, Podvinec M, Verrijdt G \& Claessens F 2008 Identification of androgen-selective androgen-response elements in the human aquaporin-5 and Rad9 genes. Biochemical Journal 411 679-686.

Naik SI, Young LS, Charlton HM \& Clayton RN 1984 Pituitary gonadotropin-releasing hormone receptor regulation in mice. I: males. Endocrinology 115 106-113.

Nef S \& Parada LF 2000 Hormones in male sexual development. Genes and Development 14 3075-3086.

Notini AJ, Davey RA, McManus JF, Bate KL \& Zajac JD 2005 Genomic actions of the androgen receptor are required for normal male sexual differentiation in a mouse model. Journal of Molecular Endocrinology 35 547-555.

Poletti A, Negri-Cesi P \& Martini L 2005 Reflections on the diseases linked to mutations of the androgen receptor. Endocrine 28 243-262.

Quigley CA, Evans BA, Simental JA, Marschke KB, Sar M, Lubahn DB, Davies P, Hughes IA, Wilson EM \& French FS 1992 Complete androgen insensitivity due to deletion of exon $\mathrm{C}$ of the androgen receptor gene highlights the functional importance of the second zinc finger of the androgen receptor in vivo. Molecular Endocrinology 6 1103-1112.

Quigley CA, De Bellis A, Marschke KB, el-Awady MK, Wilson EM \& French FS 1995 Androgen receptor defects: historical, clinical, and molecular perspectives. Endocrine Reviews 16 271-321.

Romano F, Tripiciano A, Muciaccia B, De Cesaris P, Ziparo E, Palombi F \& Filippini A 2005 The contractile phenotype of peritubular smooth muscle cells is locally controlled: possible implications in male fertility. Contraception 72 294-297. 
Sauer B 1998 Inducible gene targeting in mice using the Cre/lox system. Methods 14 381-392.

Schauwaers K, De Gendt K, Saunders PT, Atanassova N, Haelens A, Callewaert L, Moehren U, Swinnen JV, Verhoeven G, Verrijdt G et al. 2007 Loss of androgen receptor binding to selective androgen response elements causes a reproductive phenotype in a knockin mouse model. PNAS 104 4961-4966.

Seethammagari MR, Xie X, Greenberg NM \& Spencer DM 2006 EZCprostate models offer high sensitivity and specificity for noninvasive imaging of prostate cancer progression and androgen receptor action. Cancer Research 66 6199-6209.

Shaffer PL, Jivan A, Dollins DE, Claessens F \& Gewirth DT 2004 Structural basis of androgen receptor binding to selective androgen response elements. PNAS $1014758-4763$.

Singh J, O'Neill C \& Handelsman DJ 1995 Induction of spermatogenesis by androgens in gonadotropin-deficient (hpg) mice. Endocrinology 136 5311-5321.

Tan KA, De Gendt K, Atanassova N, Walker M, Sharpe RM, Saunders PT, Denolet E \& Verhoeven G 2005 The role of androgens in sertoli cell proliferation and functional maturation: studies in mice with total or Sertoli cell-selective ablation of the androgen receptor. Endocrinology 146 2674-2683.

Tsai MJ \& O'Malley BW 1994 Molecular mechanisms of action of steroid/thyroid receptor superfamily members. Annual Review of Biochemistry 63 451-486.

Tsai MY, Yeh SD, Wang RS, Yeh S, Zhang C, Lin HY, Tzeng CR \& Chang C 2006 Differential effects of spermatogenesis and fertility in mice lacking androgen receptor in individual testis cells. PNAS 103 18975-18980.

Vornberger W, Prins G, Musto NA \& Suarez-Quian CA 1994 Androgen receptor distribution in rat testis: new implications for androgen regulation of spermatogenesis. Endocrinology 134 2307-2316.

Wang Q, Li W, Liu XS, Carroll JS, Janne OA, Keeton EK, Chinnaiyan AM, Pienta KJ \& Brown M 2007 A hierarchical network of transcription factors governs androgen receptor-dependent prostate cancer growth. Molecular Cell 27 380-392.

Wilson JD, Griffin JE \& Russell DW 1993 Steroid 5 alpha-reductase 2 deficiency. Endocrine Reviews 14 577-593.

Wreford NG, Rajendra Kumar T, Matzuk MM \& de Kretser DM 2001 Analysis of the testicular phenotype of the follicle-stimulating hormone beta-subunit knockout and the activin type II receptor knockout mice by stereological analysis. Endocrinology 142 2916-2920.
Xu Q, Lin HY, Yeh SD, Yu IC, Wang RS, Chen YT, Zhang C, Altuwaijri S, Chen LM, Chuang KH et al. 2007 Infertility with defective spermatogenesis and steroidogenesis in male mice lacking androgen receptor in Leydig cells. Endocrine 32 96-106.

Ye X, Han SJ, Tsai SY, DeMayo FJ, Xu J, Tsai MJ \& O’Malley BW 2005 Roles of steroid receptor coactivator (SRC)-1 and transcriptional intermediary factor (TIF) 2 in androgen receptor activity in mice. PNAS 102 9487-9492.

Yeh S, Tsai MY, Xu Q, Mu XM, Lardy H, Huang KE, Lin H, Yeh SD, Altuwaijri S, Zhou X et al. 2002 Generation and characterization of androgen receptor knockout (ARKO) mice: an in vivo model for the study of androgen functions in selective tissues. PNAS $\mathbf{9 9}$ 13498-13503.

Yong EL, Loy CJ \& Sim KS 2003 Androgen receptor gene and male infertility. Human Reproduction Update 9 1-7.

Yu Z, Dadgar N, Albertelli M, Gruis K, Jordan C, Robins DM \& Lieberman AP 2006a Androgen-dependent pathology demonstrates myopathic contribution to the Kennedy disease phenotype in a mouse knock-in model. Journal of Clinical Investigation 116 2663-2672.

Yu Z, Dadgar N, Albertelli M, Scheller A, Albin RL, Robins DM \& Lieberman AP 2006 $b$ Abnormalities of germ cell maturation and sertoli cell cytoskeleton in androgen receptor 113 CAG knock-in mice reveal toxic effects of the mutant protein. American Journal of Pathology 168 195-204.

Zhang C, Yeh S, Chen YT, Wu CC, Chuang KH, Lin HY, Wang RS, Chang YJ, Mendis-Handagama C, Hu L et al. 2006 Oligozoospermia with normal fertility in male mice lacking the androgen receptor in testis peritubular myoid cells. PNAS 103 17718-17723.

Zhou Q, Nie R, Prins GS, Saunders PT, Katzenellenbogen BS \& Hess RA 2002 Localization of androgen and estrogen receptors in adult male mouse reproductive tract. Journal of Andrology 23 870-881.

Zuccarello D, Ferlin A, Vinanzi C, Prana E, Garolla A, Callewaert L, Claessens F, Brinkmann AO \& Foresta C 2008 Detailed functional studies on androgen receptor mild mutations demonstrate their association with male infertility. Clinical Endocrinology 68 580-588.

\section{Received in final form 10 October 2008 Accepted 15 October 2008}

Made available online as an Accepted Preprint 15 October 2008 